\title{
The subtle nuances of intranasal corticosteroids
}

\author{
James Fowler, Brian W. Rotenberg and Leigh J. Sowerby * (D)
}

\begin{abstract}
Background: In the specialty of Otolaryngology - Head and Neck Surgery, intranasal corticosteroids are the mainstay treatment for inflammatory processes within the nasal cavity. All too often, physician prescribing patterns are based on previous training, personal experience, and interactions with industry. The purpose of this commentary is to review the nuances of each intranasal corticosteroid.

Commentary: There are nine intranasal corticosteroids approved for use in Canada. Each are discussed in detail, including their indication, bioavailability, effects on intranasal environment, and factors around patient adherence. Off-label use of budesonide irrigations is also discussed and cost information is presented in reference format for all available intranasal corticosteroids.

Conclusion: Although the efficacy of each intranasal corticosteroid has been shown to be similar, prescribing should be tailored based on bioavailability, intranasal environment, and factors that impact patient adherence such as dosing, cost and tolerability.
\end{abstract}

Keywords: Intranasal corticosteroid, Rhinitis, Rhinosinusitis

\section{Background}

In the specialty of Otolaryngology - Head and Neck Surgery, intranasal corticosteroids (INCS) $\mathrm{s}$ are the mainstay treatment for inflammatory processes within the nasal cavity. Currently, there are nine INCSs available in Canada (Table 1). The utility of INCSs can be appreciated by their pharmacodynamics. Structurally, the steroids are different, but they all work in a similar manner. Intranasal corticosteroids affect both early and late inflammatory response by inhibiting the production of pro-inflammatory cytokines, inflammatory enzymes, lymphocyte proliferation, and delayed hypersensitivity [4].

Intranasal corticosteroids are the primary monotherapy, or adjunct therapy, for many rhinological conditions. Numerous studies have shown their effectiveness in treating allergic/non-allergic rhinitis, [2] acute

\footnotetext{
* Correspondence: Leigh.Sowerby@sjhc.london.on.ca

Department of Otolaryngology - Head and Neck Surgery, Western University, 3St. Joseph's Hospital, 268 Grosvenor Street, London, ON N6A 4V2, Canada
}

rhinosinusitis, [3] chronic rhinosinusitis with nasal polyposis (CRSwNP) [2], chronic rhinosinusitis without polyposis (CRSsNP [2], and adenoid hypertrophy [5]. Objectively, INCSs have demonstrated significant efficacy for reducing relative/instantaneous total nasal symptom scores (rTNSS and iTNSS, scored out of 24) [6-10], relative/instantaneous total occular symptom scores (rTOSS and iTOSS, scored out of 18) [6, 10-12], and endoscopic polyposis scores (scale 0-3) [13-18]. Regular use of INCSs is also associated with increases in peak nasal inspiratory flow $[9,19,20]$ and improved quality of life (Rhinoconjunctivitis Quality of Life Questionnaire) $[6,8,9,20]$.

Although the efficacy for each INCS is roughly equivalent [4], there are subtle characteristics to be considered when prescribing for a patient. All too often, physician prescribing patterns are based on previous training, personal experience, and interactions with industry. The purpose of this paper is to review the nuances of each

(c) The Author(s). 2021 Open Access This article is licensed under a Creative Commons Attribution 4.0 International License, which permits use, sharing, adaptation, distribution and reproduction in any medium or format, as long as you give appropriate credit to the original author(s) and the source, provide a link to the Creative Commons licence, and indicate if changes were made. The images or other third party material in this article are included in the article's Creative Commons licence, unless indicated otherwise in a credit line to the material. If material is not included in the article's Creative Commons licence and your intended use is not permitted by statutory regulation or exceeds the permitted use, you will need to obtain permission directly from the copyright holder. To view a copy of this licence, visit http://creativecommons.org/licenses/by/4.0/ The Creative Commons Public Domain Dedication waiver (http://creativecommons.org/publicdomain/zero/1.0/) applies to the data made available in this article, unless otherwise stated in a credit line to the data. 
Table 1 Summary of intranasal corticosteroids available in Canada, including indication, bioavailability, fragrance, and cost

\begin{tabular}{|c|c|c|c|c|c|}
\hline Intranasal Corticosteroid & Indications $[1,2]$ & $\begin{array}{l}\text { Bioavailability } \\
{[1,3]}\end{array}$ & Fragrance & $\begin{array}{l}\text { Cost per Bottle } \\
\text { Brand (Generic) }\end{array}$ & $\begin{array}{l}\text { Cost per Spray } \\
\text { Brand (Generic) }\end{array}$ \\
\hline $\begin{array}{l}\text { Beclomethasone dipropionate } \\
\text { Beconase AQ }(50 \mathrm{mcg})\end{array}$ & $\begin{array}{l}\text { - Allergic rhinitis } \\
\text { - Non-allergic rhinitis } \\
\text { - Chronic rhinosinusitis with } \\
\text { NP }\end{array}$ & $44 \%$ & Scented & $\$ 31(\$ 14)$ & $16 \zeta(7 \zeta)$ \\
\hline $\begin{array}{l}\text { Budesonide }{ }^{@} \text { Rhinocort Aqua (64 } \\
\left.\text { mcg, }^{1} 100 \mathrm{mcg}^{2}\right) \\
\text { Pulmicort nebule }\left(0.25^{3}, 0.5^{4}, 1 \mathrm{mg}^{5}\right) \\
\text { Rhinocort Turbuhaler* }\left(100 \mathrm{mcg}^{6} \text {-off }\right. \\
\text { market) }\end{array}$ & $\begin{array}{l}\text { - Allergic rhinitis } \\
\text { - Non-allergic rhinitis } \\
\text { - Chronic rhinosinusitis with } \\
\text { nasal polyposis } \\
\text { - Wet nasal congestion } \\
\text { (Turbuhaler) }\end{array}$ & $\begin{array}{l}\text { Spray: } \mathbf{3 1 \%} \\
\text { Turbuhaler: } \\
\mathbf{2 2} \%\end{array}$ & Non-scented & $\begin{array}{l}\text { 1. } \$ 13(\$ 12) \\
\text { 2. } \$ 26(\$ 22) \\
\text { 3. } \$ 11(\mathrm{~N} / \mathrm{A})^{*} \\
\text { 4. } \$ 23(\mathrm{~N} / \mathrm{A})^{*} \\
\text { 5. } \$ 42(\$ 32)^{*} \\
\text { 6. } \$ 29(\mathrm{~N} / \mathrm{A}) \\
{ }^{*} \text { per box of } 20\end{array}$ & $\begin{array}{l}\text { 1. } 11 \zeta(10 \zeta) \\
\text { 2. } 16 \zeta(13 \zeta) \\
\text { 3. } 54 \zeta(43 \zeta)^{*} \\
\text { 4. } \$ 1.15(\mathrm{~N} / \mathrm{A})^{*} \\
\text { 5. } \$ 2.10(\$ 1.60)^{*} \\
\text { 6. } 15 \zeta(\mathrm{N} / \mathrm{A}) \\
{ }^{*} \text { cost per nebule }\end{array}$ \\
\hline Ciclesonide Omnaris (50 mcg) & $\begin{array}{l}\text { - Perennial allergic rhinitis } \\
\text { - Seasonal allergic rhinitis } \\
\text { - Dry nasal congestion }\end{array}$ & $<1 \%$ & Non-scented & $\$ 32(\$ N / A)$ & $27 \zeta(N / A)$ \\
\hline Flunisolide Rhinalar (25 mcg) & - Seasonal allergic rhinitis & $49 \%$ & Non-scented & N/A (N/A) & N/A (N/A) \\
\hline $\begin{array}{l}\text { Fluticasone - azelastine Dymista } \\
(137 \mathrm{mcg} / 50 \mathrm{mcg})\end{array}$ & - Seasonal allergic rhinitis & $0.8 \%$ & Non-scented & $\$ 120(\mathrm{~N} / \mathrm{A})$ & $\$ 1(N / A)$ \\
\hline $\begin{array}{l}\text { Fluticasone furoate Avamys ( } 27.5 \\
\mathrm{mcg} \text { ) }\end{array}$ & $\begin{array}{l}\text { - Allergic rhinitis } \\
\text { - Non-allergic rhinitis }\end{array}$ & $0.5 \%$ & Non-scented & $\$ 33(N / A)$ & $27 \zeta(N / A)$ \\
\hline $\begin{array}{l}\text { Fluticasone propionate Flonase (50 } \\
\mathrm{mcg})\end{array}$ & $\begin{array}{l}\text { - Allergic rhinitis } \\
\text { - Non-allergic rhinitis }\end{array}$ & $0.5 \%$ & Scented & $\$ 36(\$ 25)$ & $30 \zeta(20 \zeta)$ \\
\hline $\begin{array}{l}\text { Mometasone furoate }{ }^{@} \text { Nasonex (50 } \\
\text { mcg) }\end{array}$ & $\begin{array}{l}\text { - Allergic rhinitis } \\
\text { - Acute sinusitis } \\
\text { - Chronic rhinosinusitis with } \\
\text { nasal polyposis } \\
\text { - Adenoid hypertrophy } \\
\text { - Wet nasal congestion }\end{array}$ & $0.5 \%$ & $\begin{array}{l}\text { non-scented } \\
\text { (was previously } \\
\text { scented) }\end{array}$ & $\$ 36(\$ 24)$ & $30 \zeta(20 \zeta)$ \\
\hline $\begin{array}{l}\text { Triamcinolone acetonide }{ }^{\circledR} \\
\text { Nasacort AQ }(55 \mathrm{mcg})\end{array}$ & - Allergic rhinitis & $46 \%$ & Non-scented & $\$ 24(\$ 22)$ & $20 \zeta(19 \zeta)$ \\
\hline
\end{tabular}

Cost data from October 2020 based on averaged information from two Ontario pharmacies. Does not include dispensing fee. ${ }^{\circledR}$ indicates coverage by Ontario Drug Benefit.

INCS, including their indication, bioavailability, intranasal environment, and patient adherence.

\section{Review}

\section{Selection of intranasal corticosteroid}

Intranasal corticosteroids can be categorized based on their generation. The older, first generation INCSs (beclomethasone dipropionate, triamcinolone acetonide, flunisolide, budesonide) have a significantly higher systemic bioavailability than the second generation INCSs (ciclesonide, fluticasone furoate, fluticasone propionate, mometasone furoate) (Table 1).

Characteristics of the nasal mucosa can also alter selection of INCS. The presence, or absence, of nasal secretions affects how the INCS is absorbed. Movement of nasal cilia can become impaired if the sol layer of mucous is too thin, or too thick [21]. This affects the permeability of the steroid, as mucociliary clearance is altered, and duration of contact between the steroid and nasal mucosa is decreased [21]. To counteract this, selection of an INCS that alters the viscosity within the nose, can increase contact time and overall diffusion of the steroid. For example, in a "dry" congested nose, ciclesonide is favoured. Ciclesonide is a hypotonic solution, resulting in rapid diffusion water molecules into the nasal mucosa of a dry nose. The difference in osmolarity increases the viscosity within the nose, thus increasing contact time [22]. A similar principle can be seen for a "wet" congested nose. In this case, mometasone furoate and budesonide (Rhinocort Turbuhaler) are recommended. Mometasone furoate contains the highest concentration of microcrystalline cellulose and carboxymethylcellulose sodium for aqueous INCS [23]. These are thixotropic agents, which dry and increase viscosity within the nasal cavity. Rhinocort Turbuhaler also dries the nose, secondary to its dry powered formulation, but as of February 2020 has been discontinued by the manufacturer. Both steroids increase viscosity, while decreasing moisture within the nasal cavity.

Although fluticasone is the backbone of both fluticasone furoate (FF - Avamys) and fluticasone propionate (FP - Flonase), one should be cognisant that their efficacies are not equivalent. The two molecules are relatively similar in structure, only differing in the esters attached to the $17 \alpha-\mathrm{OH}$ group (Fig. 1a-d). Esterified furoate and propionic acid are found at this location for fluticasone 


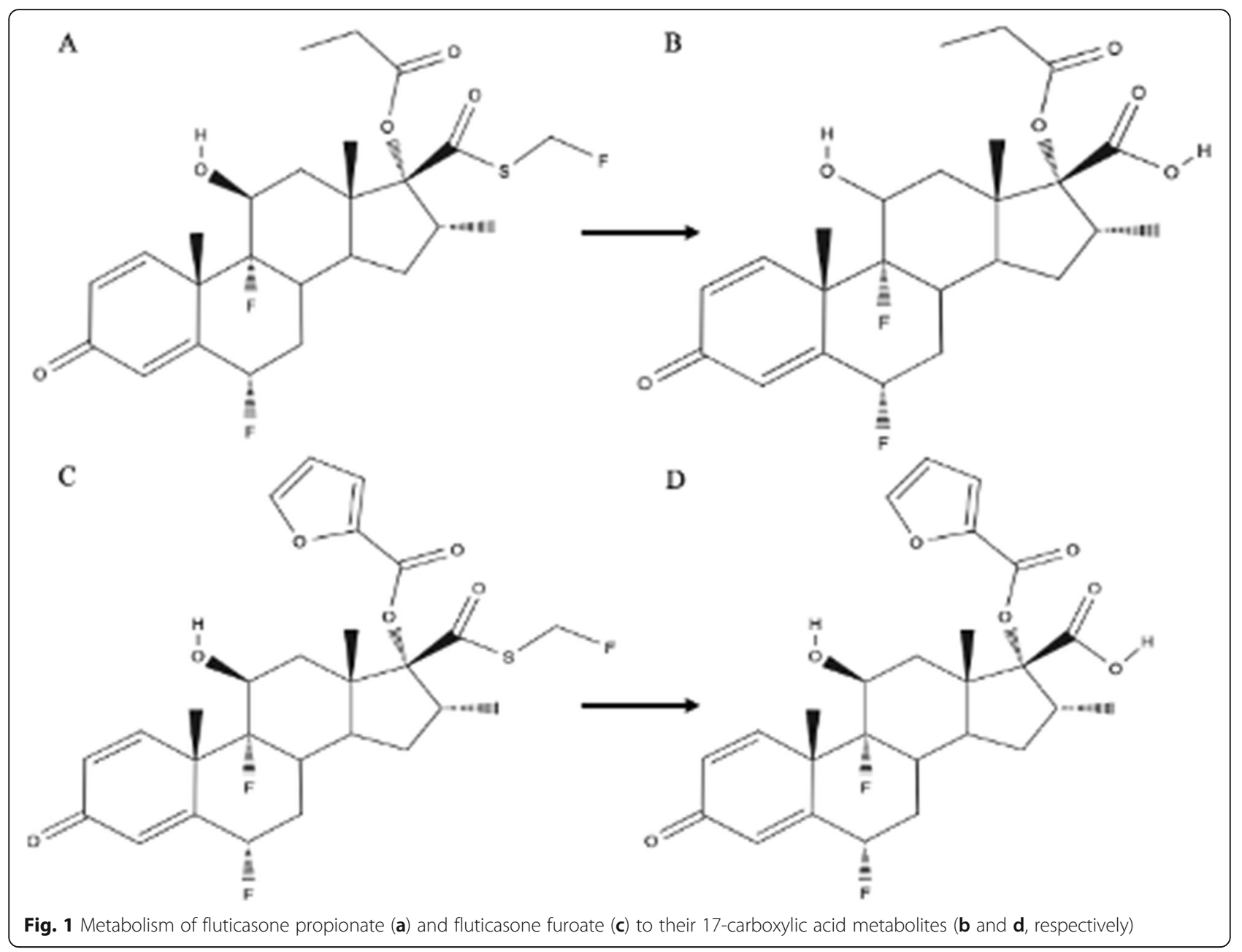

furoate and fluticasone propionate, respectively [24]. When metabolized, fluticasone is not released from the ester substituent, which affects target receptor binding [25]. The ester sidechain of fluticasone furoate is much larger than that of fluticasone propionate. This structural difference allows fluticasone furoate to bind to the glucocorticoid receptor with a higher affinity [26]. Valotis et al. [27] report that fluticasone furoate has a relative receptor affinity ratio (in comparison to dexamethasone) of 2989, while fluticasone propionate has an affinity of 1775. Clinically, this results in superior efficacy for fluticasone furoate (Avamys) [24, 26, 28].

Fluticasone propionate-azelastine (Dymista) is unique. Produced in 2012, it combines the therapeutic effects of a corticosteroid and an antihistamine. Fluticasoneazelastine is effective in treating severe seasonal allergic rhinitis refractory to steroid or antihistamine treatment alone [1]. The combination spray results in an incremental improvement of around 1 over and above FP on the Total Nasal Symptom Score (TNSS), and doubles the small reduction seen on the Total Ocular Symptom Score (TOSS) with FP alone [29]. Dymista achieved a reduction of TNSS to one or less in $12 \%$ of patients, versus $9.5 \%$ for FP, and had $35 \%$ of patients achieve a $50 \%$ reduction in TNSS by day 7, versus day 9 for INCS alone and day 11 for azelastine [29]. The bioavailability of the fluticasone component is low, but is $44-61 \%$ higher than monotherapy FP [30]. This is a negligible difference as the bioavailability of monotherapy FP is $<0.5 \%$ [1]. Adverse effects are rare $(<5 \%)$, and have a similar side effect profile to other INCSs [1]. Given the cost-benefit ratio, it generally should be reserved as a second line therapy after failure of another INCS.

Budesonide nebules (Pulmicort) are approved as a maintenance therapy for asthma. In recent years, this medication has been used "off-label" to treat CRSwNP before or after endoscopic sinus surgery and has become widely accepted as maximal medical therapy for this condition. Budesonide nebules are produced in various concentrations $(0.25 \mathrm{mg}, 0.5 \mathrm{mg}$, and $1 \mathrm{mg}$ per $2 \mathrm{~mL})$ and are mixed with saline to irrigate the nasal cavity. Multiple studies have shown that budesonide irrigations are efficacious in treating nasal polyposis by improving both Lund-Kennedy endoscopic scores and Sinonasal 
Outcomes Test (SNOT-22) scores [31-33]. The dosage used in reported trials is between $128 \mu \mathrm{g}-2 \mathrm{mg}$ per day, divided per nostril either once or twice daily [2]. The exact bioavailability of the budesonide irrigation is unknown, but it is believed to be less than typical INCSs, as less than $5 \%$ of the solution remains in the sinuses when administered with a squeeze bottle [34]. Systemic side effects are minimal, as very little solution remains in the nasal cavity. In two short-term safety studies, no evidence of HPA axis suppression was found [35, 36]. In regards to long-term safety, Smith et al. evaluated patients using $2 \mathrm{mg}$ of budesonide in daily irrigations for an average of 3 years without evidence of any hypothalamic-pituitary-adrenal (HPA) axis suppression in 35 patients [37]. Soudry et al. [38] evaluated 48 patients after a mean duration of 22 months with daily budesonide irrigations (mean daily dose of $0.75 \mathrm{mg}$ ) and all demonstrated normal intraocular pressures. They did, however, find low levels of stimulated cortisol in 11 (23\%) patients but all were without symptoms of adrenal suppression. Risk of suppression was strongly associated with concurrent pulmonary steroid inhalers and suppression reversed in $75 \%$ after cessation of budesonide rinses for 1 month [38]. As such, for patients on concurrent inhaled corticosteroids consideration should be given to using the lowest budesonide dose that can control symptoms. A referral to endocrinology to test for subclinical HPA axis suppression via ACTH stimulation testing is an option in select cases, but is not currently part of routine standard practice.

Lastly, symptom management is dependent on adherence to the INCS. Three factors affecting INCS adherence are patient preference, ease of use, and affordability. Patient preference is strongly related to sensory attributes associated with INCS. Scent and aftertaste of the INCS greatly impact regular use. As sensory attributes increase, patient preference for the INCS decreases $[39,40]$. Scented INCS, (beclomethasone dipropionate, fluticasone propionate) often have an accompanied aftertaste. Fluticasone-azelastine also has a strong aftertaste. If a patient has reported sensitivity to scents, it is recommended to prescribe a non-scented formulation. Use of a mouthwash gargle prior to application of the spray can help mitigate this side-effect. Delivery is also important to consider - some of the bottles have longer nozzles that are easier to place in the nasal cavity, whereas Avamys has a side-action to activate, increasing ease of use with issues of manual dexterity. With respect to affordability, many generic INCS are covered by provincial drug plans. If the INCS is not listed on the designated formulary, it is important to have a discussion with the patient about additional drug coverage, or willingness to pay out-of-pocket. Coverage by the Ontario Drug Benefit and the estimated costs per spray based on data from Ontario in October 2020 are included in Table 1.

\section{Side-effects}

In general, the risk of systemic side effects for INCSs are very low [41]. An early study by Skoner et al. [3] showed that beclomethasone dipropionate had a negative impact on pediatric growth velocity. In this study, 90 children with perennial rhinitis were randomly assigned to a treatment or placebo group. The treatment group received beclomethasone dipropionate $168 \mu \mathrm{g}$ twice daily for 1 year. Patient height was measured monthly with a stadiometer. At the end of the study, the mean change in height was $5 \mathrm{~cm}$ and $5.9 \mathrm{~cm}$, for the treatment and placebo respectively. The authors noted that slowing of the growth was evident within the first month of beclomethasone dipropionate use. Mometasone furoate [42], fluticasone propionate [43], triamcinolone acetonide [44], fluticasone furoate [45], and ciclesonide [46] have all since been studied for growth impairment in pediatric patients, and none of these INCSs impaired growth. With respect to HPA axis suppression, a review by Sheth [47] revealed no correlation between HPA axis suppression and traditional INCSs. Of note, long term off-label use of budesonide for treatment of CRSwNP has been correlated in one study with subclinical HPA axis suppression in patients on concurrent inhaled corticosteroids [27]. It is important to note that this suppression was without clinical manifestations of adrenal sufficiency, and all patients were able to continue corticosteroid therapy safely, and at least three other studies have found no evidence of HPA axis suppression [35, 36]. Lastly, a recent systematic review by Valenzuela et al. [48] analysed the effect of INCSs on intraocular pressure. Their metaanalysis found that there was no association with increased intraocular pressure and INCSs. There were also no diagnoses of glaucoma at 12 months of regular use. While these studies are reassuring that the amount of corticosteroid absorbed is quite low, there is a theoretical increased risk for patients on concurrent oral/inhaled corticosteroids. In this setting, a second generation INCS, with low bioavailability, would be recommended.

Local effects, such as burning/stinging $(<10 \%)$, dryness $(<10 \%)$, and epistaxis $(<10 \%)$, are common regardless of bioavailability [4]. The incidence of epistaxis is higher with some sprays, such as mometasone (12.7\%), fluticasone propionate (19\%), and fluticasone furoate $(20 \%)$ with prolonged use [49]. Septal perforation is reported as a complication, but the incidence is very low $(<0.001 \%)$, and clear causality has not been established [50]. 


\section{Conclusion}

In summary, INCSs have become the mainstay conservative management for many rhinological conditions. Within the literature, studies have shown the efficacy of INCSs to be very similar. Although this statement is true, there are subtle nuances that should be considered when selecting medication to prescribe. Prescribing should be tailored based on bioavailability, intranasal environment, and factors that impact patient adherence.

\begin{abstract}
Abbreviations
CRSsNP: Chronic rhinosinusitis without nasal polyposis; CRSwNP: Chronic rhinosinusitis with nasal polyposis; FF: Fluticasone furoate; FP: Fluticasone propionate; HPA: Hypothalamic-pituitary-adrenal; INCS: Intranasal corticosteroid; iTNSS: Instantaneous total nasal symptom score; iTOSS: Instantaneous total occular symptom score; rTNSS: Relative total nasal symptom score; rTOSS: Relative total occular symptom score; SNOT22: Sinonasal Outcomes Test; TNSS: Total nasal symptom score; TOSS: Total occular symptom score
\end{abstract}

\section{Acknowledgements}

Not applicable.

\section{Authors' contributions}

JF and LJS preformed the literature review. LJS and BWR proposed the idea for this report. All authors wrote, reviewed, and edited the manuscript. All authors read and approved the final manuscript before submission.

\section{Funding}

The authors declare there is no funding to disclose.

\section{Availability of data and materials}

Not applicable.

\section{Ethics approval and consent to participate}

Not applicable.

\section{Consent for publication}

Not applicable.

\section{Competing interests}

LJS has received speaking fees from Mylan and Sanofi, and has received clinical trial support from Optinose, Astra Zeneca, GSK, and Roche.

Received: 3 June 2020 Accepted: 16 November 2020

Published online: 17 March 2021

\section{References}

1. Wise SK, Lin SY, Toskala E, Orlandi RR, Akdis CA, Alt JA, Azar A, Baroody FM, Bachert C, Canonica GW, Chacko T. International consensus statement on allergy and rhinology: allergic rhinitis. Int Forum Allergy Rhinol. 2018;8(2): $108-352$.

2. Orlandi RR, Kingdom TT, Hwang PH, Smith TL, Alt JA, Baroody FM, Batra PS, Bernal-Sprekelsen M, Bhattacharyya N, Chandra RK, Chiu A. International consensus statement on allergy and rhinology: rhinosinusitis. Int Forum Allergy Rhinol. 2016;6:S22-S209

3. Skoner DP, Rachelefsky GS, Meltzer EO, Chervinsky P, Morris RM, Seltzer JM Storms WW, Wood RA. Detection of growth suppression in children during treatment with intranasal beclomethasone dipropionate. Pediatrics. 2000; 105(2):e23.

4. Benninger MS, Ahmad N, Marple BF. The safety of intranasal steroids. Otolaryngol Head Neck Surg. 2003;129(6):739-50

5. Berlucchi M, Salsi D, Valetti L, Parrinello G, Nicolai P. The role of mometasone furoate aqueous nasal spray in the treatment of adenoidal hypertrophy in the pediatric age group: preliminary results of a prospective, randomized study. Pediatrics. 2007;119(6):e1392-7.

6. Rodrigo GJ, Neffen $\mathrm{H}$. Efficacy of fluticasone furoate nasal spray vs. placebo for the treatment of ocular and nasal symptoms of allergic rhinitis: a systematic review. Clin Exp Allergy. 2011:41:160-70.
7. Penagos M, Compalati E, Tarantini F, Baena Cagnani CE, Passalacqua G, Canonica GW. Efficacy of mometasone furoate nasal spray in the treatment of allergic rhinitis. Meta-analysis of randomized, double-blind, placebocontrolled, clinical trials. Allergy. 2008;63:1280-91.

8. Yamada $T$, Yamamoto $H$, Kubo $S$, et al. Efficacy of mometasone furoate nasal spray for nasal symptoms, quality of life, rhinitis-disturbed sleep, and nasal nitric oxide in patients with perennial allergic rhinitis. Allergy Asthma Proceed. 2012;33:e9-e16.

9. Meltzer EO, Munafo DA, Chung W, Gopalan G, Varghese ST. Intranasal mometasone furoate therapy for allergic rhinitis symptoms and rhinitis disturbed sleep. Ann Allergy Asthma Immunol. 2010;105:65-74.

10. Kaiser HB, Naclerio RM, Given J, Toler TN, Ellsworth A, Philpot EE. Fluticasone furoate nasal spray: a single treatment option for the symptoms of seasonal allergic rhinitis. J Allergy Clin Immunol. 2007;119:1430-7.

11. DeWester J, Philpot EE, Westlund RE, Cook CK, Rickard KA. The efficacy of intranasal fluticasone propionate in the relief of ocular symptoms associated with seasonal allergic rhinitis. Allergy Asthma Proceed. 2003;24:331-7.

12. Ratner $P$, Van Bavel J, Mohar D, et al. Efficacy of daily intranasal fluticasone propionate on ocular symptoms associated with seasonal allergic rhinitis. Ann Allergy Asthma Immunol. 2015;114:141-7.

13. Jankowski $R$, Schrewelius $C$, Bonfils $P$, et al. Efficacy and tolerability of budesonide aqueous nasal spray treatment in patients with nasal polyps. Arch Otolaryngol Head Neck Surg. 2001;127:447-52.

14. Johansson L, Holmberg K, Melen I, et al. Sensitivity of a new grading system for studying nasal polyps with the potential to detect early changes in polyp size after treatment with a topical corticosteroid (budesonide). Acta Otolaryngol. 2002;122:49-53.

15. Vlckova I, Navratil P, Kana R, et al. Effective treatment of mild-to-moderate nasal polyposis with fluticasone delivered by a novel device. Rhinology. 2009:47:419-26.

16. Stjarne $\mathrm{P}$, Olsson P, Alenius M. Use of mometasone furoate to prevent polyp relapse after endoscopic sinus surgery. Arch Otolaryngol Head Neck Surg. 2009;135:296-302.

17. Jankowski R, Klossek JM, Attali V, et al. Longterm study of fluticasone propionate aqueous nasal spray in acute and maintenance therapy of nasal polyposis. Allergy. 2009;64:944-50.

18. Vento SI, Blomgren K, Hytonen M, et al. Prevention of relapses of nasal polyposis with intranasal triamcinolone acetonide after polyp surgery: a prospective double-blind, placebo-controlled, randomised study with a 9month follow-up. Clin Otolaryngol. 2012;37:117-23.

19. Day JH, Briscoe MP, Rafeiro E, Ellis AK, Pettersson E, Akerlund A. Onset of action of intranasal budesonide (Rhinocort aqua) in seasonal allergic rhinitis studied in a controlled exposure model. J Allergy Clin Immunol. 2000;105:489-94.

20. Fokkens WJ, Cserhati E, dos Santos JM, et al. Budesonide aqueous nasal spray is an effective treatment in children with perennial allergic rhinitis, with an onset of action within 12 hours. Ann Allergy Asthma Immunol. 2002;89:279-84.

21. Thorat S. Formulation and product development of nasal spray: an overview. Scholars J Appl Med Sci. 2016:4:2976-85.

22. Neffen $H$, Wingertzahn MA. Ciclesonide, a hypotonic intranasal corticosteroid. Allergy \& Asthma Proceedings. 2010; 31(3).

23. Sharpe SA, Sandweiss V, Tuazon J, Giordano M, Witchey-Lakshmanan L, Hart J, Sequeira J. Comparison of the flow properties of aqueous suspension corticosteroid nasal sprays under differing sampling conditions. Drug Dev Ind Pharm. 2003;29(9):1005-12.

24. Kariyawasam HH, Scadding GK. Seasonal allergic rhinitis: fluticasone propionate and fluticasone furoate therapy evaluated. J Asthma Allergy. 2010;3:19.

25. Biggadike K. Fluticasone furoate/fluticasone propionate-different drugs with different properties. Clin Respir J. 2011;5(3):183.

26. Okubo K, Nakashima M, Miyake N, Komatsubara M, Okuda M. Comparison of fluticasone furoate and fluticasone propionate for the treatment of Japanese cedar pollinosis. Allergy Asthma Proceed. 2009;30(1):84-94.

27. Valotis A, Högger P. Human receptor kinetics and lung tissue retention of the enhanced-affinity glucocorticoid fluticasone furoate. Respir Res. 2007;8(1):54.

28. Salter M, Biggadike K, Matthews JL, West MR, Haase MV, Farrow SN, Uings IJ, Gray DW. Pharmacological properties of the enhanced-affinity glucocorticoid fluticasone furoate in vitro and in an in vivo model of respiratory inflammatory disease. Am J Phys Lung Cell Mol Phys. 2007:293(3):L660-7.

29. Carr W, Bernstein J, Lieberman P, Meltzer E, Bachert C, Price D, Munzel U, Bousquet J. A novel intranasal therapy of azelastine with fluticasone for the treatment of allergic rhinitis. J Allergy Clin Immunol. 2012;129(5):1282-9. 
30. Derendorf H, Munzel U, Petzold U, Maus J, Mascher H, Hermann R, Bousquet J. Bioavailability and disposition of azelastine and fluticasone propionate when delivered by MP29-02, a novel aqueous nasal spray. Br J Clin Pharmacol. 2012;74(1):125-33.

31. Huang ZZ, Chen XZ, Huang JC, Wang ZY, Li X, Chen XH, Lai XP, Chang LH, Zhang GH. Budesonide nasal irrigation improved Lund-Kennedy endoscopic score of chronic rhinosinusitis patients after endoscopic sinus surgery. Eur Arch Otorhinolaryngol. 2019;276(5):1397-403.

32. Kang TW, Chung JH, Cho SH, Lee SH, Kim KR, Jeong JH. The effectiveness of budesonide nasal irrigation after endoscopic sinus surgery in chronic rhinosinusitis with asthma. Clin Exp Otorhinolaryngol. 2017;10(1):91.

33. Neubauer PD, Schwam ZG, Manes RP. Comparison of intranasal fluticasone spray, budesonide atomizer, and budesonide respules in patients with chronic rhinosinusitis with polyposis after endoscopic sinus surgery. Int Forum Allergy Rhinol. 2016;6(3):233-7.

34. Harvey RJ, Goddard JC, Wise SK, Schlosser RJ. Effects of endoscopic sinus surgery and delivery device on cadaver sinus irrigation. Otolaryngol Head Neck Surg. 2008;139(1):137-42.

35. Bhalla RK, Payton K, Wright ED. Safety of budesonide in saline sinonasal irrigations in the management of chronic rhinosinusitis with polyposis: lack of significant adrenal suppression. J Otolaryngol Head Neck Surg. 2008 Dec; 37(6):821-5. 19128710.

36. Welch KC, Thaler ER, Doghramji LL, Palmer JN, Chiu AG. The effects of serum and urinary cortisol levels of topical intranasal irrigations with budesonide added to saline in patients with recurrent polyposis after endoscopic sinus surgery. Am J Rhinol Allergy. 2010;24(1):26-8. 20109316. https://doi.org/10.2500/ajra.2010.24.3418.

37. Smith KA, French G, Mechor B, Rudmik L. Safety of long-term high-volume sinonasal budesonide irrigations for chronic rhinosinusitis. Int Forum Allergy Rhinol. 2016;6(3):228-32.

38. Soudry E, Wang J, Vaezeafshar R, Katznelson L, Hwang PH. Safety analysis of long-term budesonide nasal irrigations in patients with chronic rhinosinusitis post endoscopic sinus surgery. Int Forum Allergy Rhinol. 2016; 6(6):568-72.

39. Petty DA, Blaiss MS. Intranasal corticosteroids topical characteristics: side effects, formulation, and volume. Am J Rhinol Allergy. 2013;27(6):510-3.

40. Klossek JM, Serrano E, Dreyfus I, Mesbah K, Demoly P. Patient preference survey on the lack of taste and odor of Nasonex nasal spray. Which impact on compliance to treatment? Revue Laryngol-Otol-Rhinol. 2008;129(1):35-41.

41. Gupta R, Fonacier LS. Adverse effects of nonsystemic steroids (inhaled, intranasal, and cutaneous): a review of the literature and suggested monitoring tool. Curr Allergy Asthma Rep. 2016;16(6):44.

42. Schenkel EJ, Skoner DP, Bronsky EA, et al. Absence of growth retardation in children with perennial allergic rhinitis after one year of treatment with mometasone furoate aqueous nasal spray. Pediatrics. 2000;105(2):E22.

43. Allen DB, Meltzer EO, Lemanske RF, et al. No growth suppression in children treated with the maximum recommended dose of fluticasone propionate aqueous nasal spray for one year. Allergy Asthma Proceed. 2002;23:407-13.

44. Skoner DP, Gentile D, Angelini B, et al. The effects of intranasal triamcinolone acetonide and intranasal fluticasone propionate on shortterm bone growth and HPA axis in children with allergic rhinitis. Ann Allergy Asthma Immunol. 2003;90:56-62.

45. Gradman J, Caldwell MF, Wolthers OD. A 2-week, crossover study to investigate the effect of fluticasone furoate nasal spray on short-term growth in children with allergic rhinitis. Clin Ther. 2007;29(8):1738-47.

46. Agertoft L, Pedersen $\mathrm{S}$. Short-term lower-leg growth rate and urine cortisol excretion in children treated with ciclesonide. J Allergy Clin Immunol. 2005;115:940-5.

47. Sheth K. Evaluating the safety of intranasal steroids in the treatment of allergic rhinitis. Allergy Asthma Clin Immunol. 2008;4(3):125.

48. Valenzuela CV, Liu JC, Vila PM, Simon L, Doering M, Lieu JE. Intranasal corticosteroids do not lead to ocular changes: a systematic review and meta-analysis. Laryngoscope. 2019;129(1):6-12.

49. Sastre J, Mosges R. 1 local and systemic safety of intranasal corticosteroids. J Investig Allergol Clin Immunol 2012;1;22(1).

50. Cervin A, Andersson M. Intranasal steroids and septum perforation-an overlooked complication? A description of the course of events and a discussion of the causes. Rhinology. 1998;36:128-32.

\section{Publisher's Note}

Springer Nature remains neutral with regard to jurisdictional claims in published maps and institutional affiliations.

Ready to submit your research? Choose BMC and benefit from:

- fast, convenient online submission

- thorough peer review by experienced researchers in your field

- rapid publication on acceptance

- support for research data, including large and complex data types

- gold Open Access which fosters wider collaboration and increased citations

- maximum visibility for your research: over $100 \mathrm{M}$ website views per year

At BMC, research is always in progress.

Learn more biomedcentral.com/submissions 